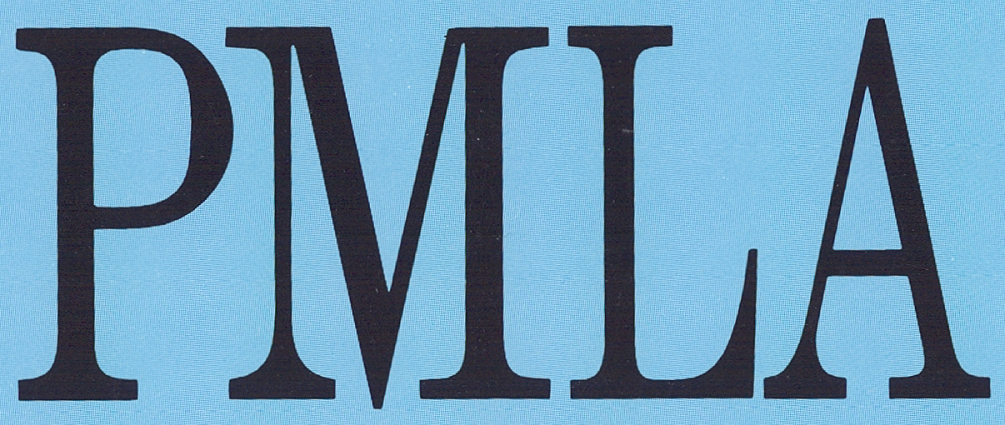

Publications of the

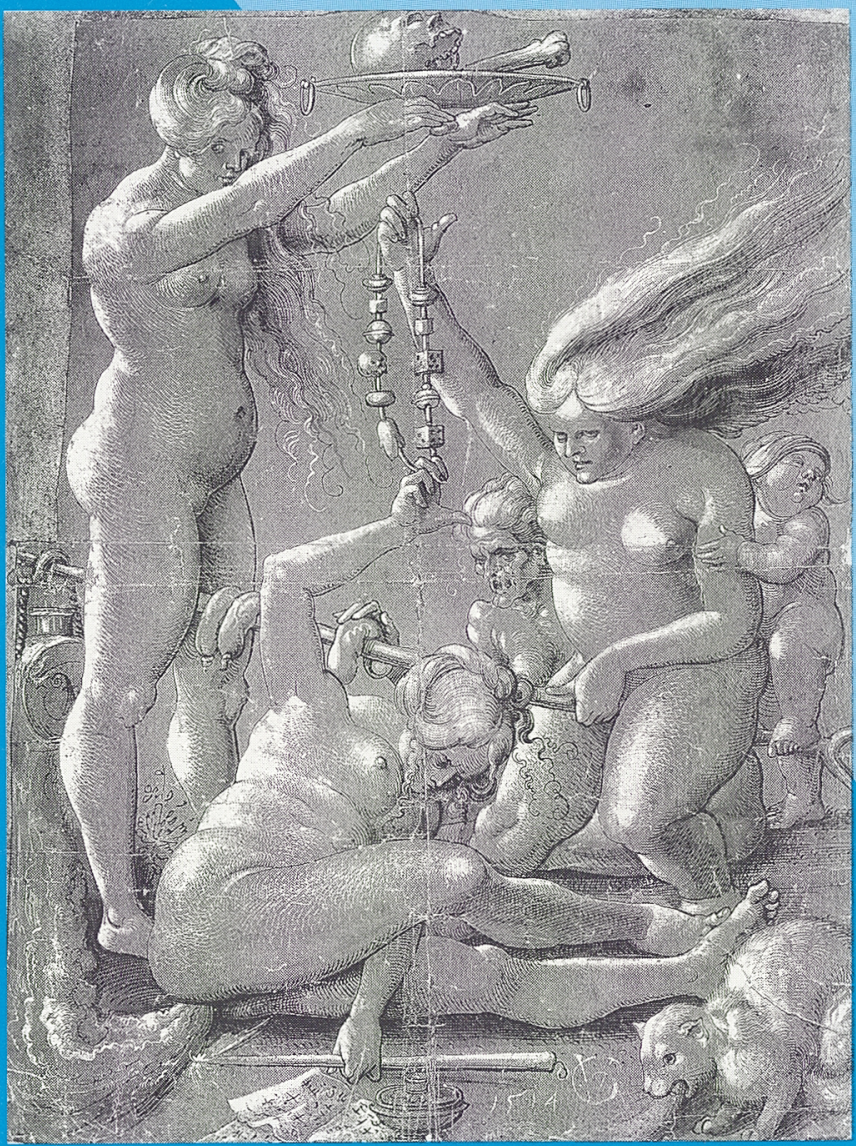

\title{
Modern Language
}

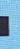

Association

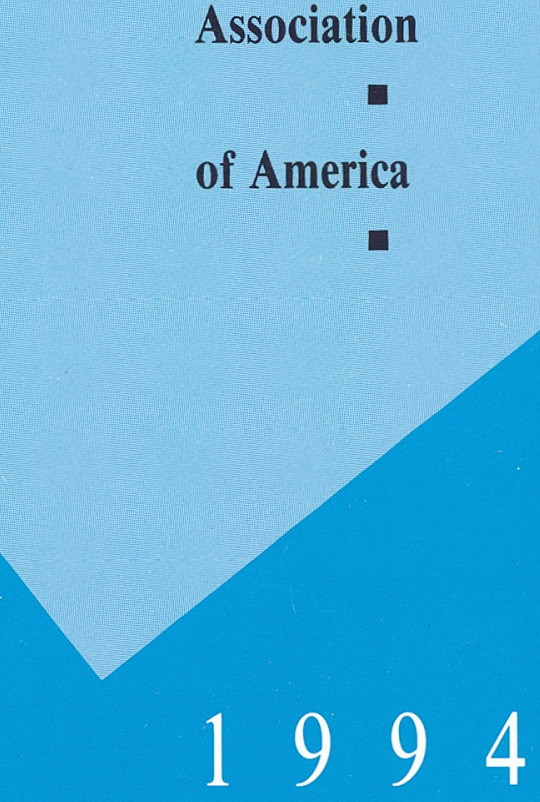

MARCH

VOLUME 109 口 NUMBER 2 


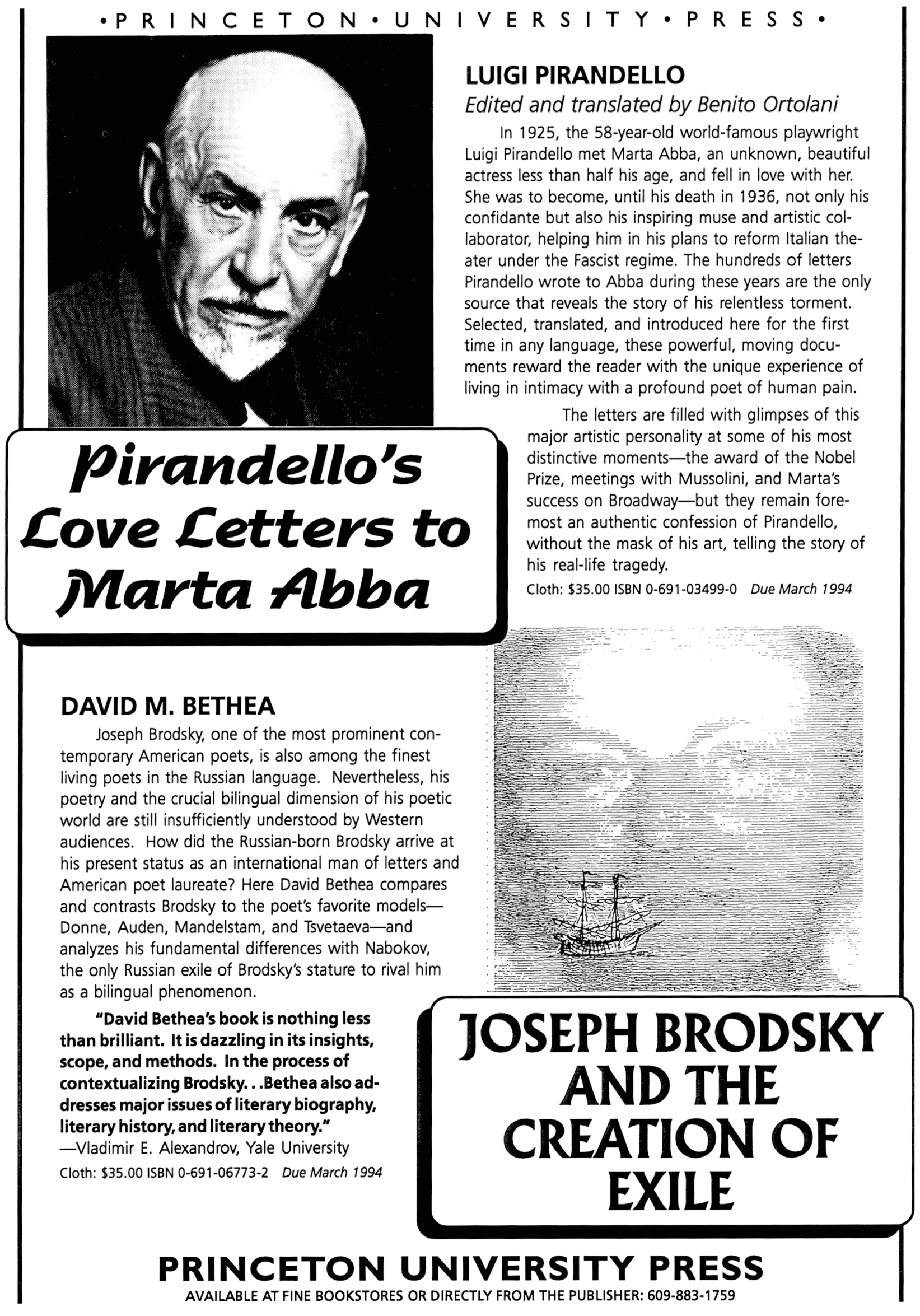




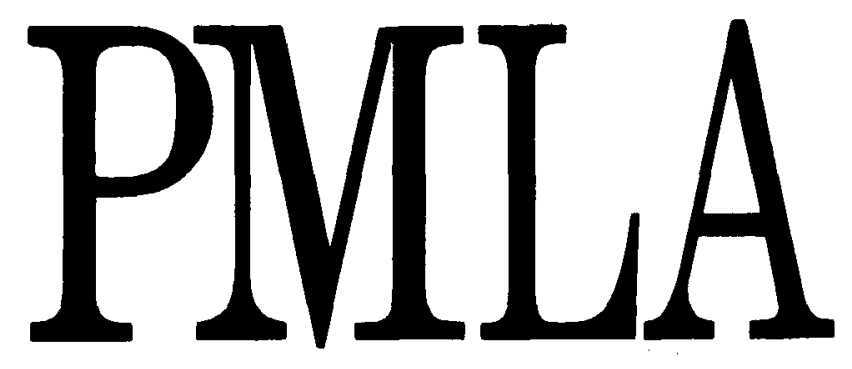

Publications of the

Modern Language Association of America

Volume 109, Number 2

Published six times a year by the association 


\section{The Modern Language Association of America}

\author{
Officers for the Year 1994 \\ Executive Council \\ For the term ending 31 December 1994
}

For the term ending 31 December 1995

For the term ending 31 December 1996

For the term ending 31 December 1997

Trustees of Invested Funds

\author{
President: PATRICIA MEYER SPACKS, University of Virginia \\ First Vice President: SANDER L. GILMAN, Cornell University \\ Second Vice President: SANDRA M. GILBERT, University of California, Davis \\ Executive Director: PHYLLIS FRANKLIN
}

STEPHEN GREENBLATT, University of California, Berkeley MICHAEL HOLQUIST, Yale University

JACK ZIPES, University of Minnesota, Minneapolis

MARTHA BANTA, University of California, Los Angeles MARIANNE HIRSCH, Dartmouth College

NAOMI SCHOR, Duke University

NANCY A. WALKER, Vanderbilt University

LINDA HUTCHEON, University of Toronto, Saint George Campus

SUSAN KIRKPATRICK, University of California, San Diego

SUSAN RUBIN SULEIMAN, Haryard University

PETER BROOKS, Yale University

ANDREA A. LUNSFORD, Ohio State University, Columbus

SYLVIA MOLLOY, New York University

SUSAN NOAKES, University of Minnesota, Twin Cities

CAROLYN G. HEILBRUN, New York, New York

HUGH O'NEILL, New York, New York

MALCOLM B. SMITH (Managing Trustee), New York, New York

PMLA (ISSN 0030-8129) is published six times a year, in January, March, May, September, October, and November, by the Modern Language Association of America. Membership in the association is open to persons who are professionally interested in the modem languages and literatures. Annual dues, which include subscription to $P M L A$, are based on members' incomes and are graduated as follows: student members (four years maximum), $\$ 20$; new regular members (first year), $\$ 35$; regular members (income under $\$ 15,000$ ), $\$ 25$; regular members (income $\$ 15,000-\$ 20,000$ ), $\$ 40$; regular members (income $\$ 20,000-\$ 30,000$ ), $\$ 50$; regular members (income $\$ 30,000-\$ 40,000$ ), $\$ 65$; regular members (income $\$ 40,000-\$ 50,000$ ), $\$ 75$; regular members (income $\$ 50,000-\$ 60,000$ ), $\$ 85$; regular members (income $\$ 60,000-\$ 70,000$ ), $\$ 95$; regular members (income $\$ 70,000 \$ 80,000$ ), $\$ 105$; regular members (income over $\$ 80,000$ ), $\$ 125$; foreign members, same as regular members (use the American-dollar equivalent to ascertain the dues category). Membership applications are available on request.

The subscription price of $P M L A$ for libraries and other institutions is $\$ 104$. A subscription including a bound volume at the end of the year is $\$ 239$, domestic and foreign. Agents deduct $4 \%$ as their fee. Single copies of the January, March, May, and October issues may be obtained for $\$ 12$ each; the September (Directory) issue for \$50; the November (Program) issue for \$35.

Issues for the current year are available from the Member and Customer Services Office of the association (212 614-6377). Claims for undelivered issues will be honored if they are received within one year of the publication date; thereafter the single-issue price will be charged.

For information about the availability of back issues, inquire of Kraus Reprint, Millwood, NY 10546; 914 762-2200. Early and current volumes may be obtained on microfilm from University Microfilms, Ann Arbor, MI 48106. Purchase of current volumes on film is restricted to subscribers of the journal.

The office of publication and editorial offices are located at 10 Astor Place, New York, NY 10003-6981; 212 475-9500.

All communications including notices of changes of address should be sent to the Member and Customer Services Office of the association.

If a change of address also involves a change of institutional affiliation, that office should be informed of this fact at the same time.

Second-class postage paid at New York, NY, and at additional mailing office.

( 1994 by The Modern Language Association of America. All rights reserved. Printed in the United States of America.

Library of Congress Catalog Card Number 12-32040. United States Postal Service Number 449-660.

POSTMASTER: Send address changes to PMLA, Member and Customer Services Office, Modern Language Association of America, 10 Astor Place, New York, NY 10003-6981. 


\section{Publications of the Modern Language Association}

Published six times a year Indexes: Vols. 1-50, 1935; 51-60, 1945; 51-79, 1964

Editorial Board

Advisory Committee
Editor: DOMNA C. STANTON, University of Michigan, Ann Arbor Managing Editor: JUDY GOULDING Assistant Editor: ERIC WIRTH Editorial Assistant: ERIN TROSTLE Advertising Manager and Administrative Assistant: CYNTHIA R. PORT Administrative Assistant: XENI FRAGAKIS

VALERIE D. GREENBERG, 1995, Tulane University SYLVIA MOLLOY, 1994, New York University PETER RABINOWITZ, 1995, Hamilton College HER BERT F. TUCKER, 1995, University of Virginia JERRY W. WARD, JR., 1994, Tougaloo College MARILYN L. WILLIAMSON, 1994, Wayne State University

JONATHAN ARAC, 1994, University of Pittsburgh, Pittsburgh NINA BAYM, 1995, University of Illinois, Urbana JOHN BEVERLEY, 1996, University of Pittsburgh, Pittsburgh RICHARD J. DELLAMORA, 1995, Champlain College, Trent University LAURIE EDSON, 1996, San Diego State University GAIL FINNEY, 1995, University of Califormia, Davis SUZANNE FLEISCHMAN, 1995, University of California, Berkeley SUSAN STANFORD FRIEDMAN, 1994, University of Wisconsin, Madison JANE A. GALLOP, 1995, University of Wisconsin, Milwaukee ARTHUR F. GANZ, 1994, City College, City University of New York CHARLES B. HARRIS, 1994, Illinois State University COPPELIA KAHN, 1994, Brown University LAWRENCE D. KRITZMAN, 1996, Dartmouth College SETH LERER, 1994, Stanford University JOSEPH F. LOEWENSTEIN, 1996, Washington University GREGORY L. LUCENTE, 1995, University of Michigan, Ann Arbor STEVEN MAILLOUX, 1996, University of California, Irvine PAUL L. MARLANI, 1994, University of Massachusetts, Amherst RICHARD MARIUS, 1996, Harvard University ADRIENNE MUNICH, 1996, State University of New York, Stony Brook RUTH PERRY, 1995, Massachusetts Institute of Technology SANDY PETREY, 1996, State University of New York, Stony Brook TILOTTAMA RAJAN, 1994, University of Western Ontario ERIC RENTSCHLER, 1995, University of California, Irvine MARGERY SABIN, 1994, Wellesley College STEPHANIE SANDLER, 1995, Amherst College DEBORA SHUGER, 1996, University of California, Los Angeles FRANK TROMMLER, 1995, University of Pennsylvania JAMES G. TURNER, 1994, University of California, Berkeley PATRICIA YAEGER, 1996, University of Michigan, Ann Arbor MARGARITA ZAMORA, 1996, University of Wisconsin, Madison 


\section{A Statement of Editorial Policy}

PMLA welcomes essays of interest to those concerned with the study of language and literature. As the publication of a large and heterogeneous association, the journal is receptive to a variety of topics, whether general or specific, and to all scholarly methods and theoretical perspectives. The ideal PMLA essay exemplifies the best of its kind, whatever the kind; addresses a significant problem; draws out clearly the implications of its findings; and engages the attention of its audience through a concise, readable presentation. Manuscripts in languages other than English are accepted for review but must be accompanied by a detailed summary in English (generally of 1,000-1,500 words) and must be translated into English if they are recommended to the Editorial Board. Articles of fewer than 2,500 words or more than 9,000 words are not considered for publication. The word count includes notes but excludes works-cited lists and translations, which should accompany foreign language quotations. The MLA urges its contributors to be sensitive to the social implications of language and to seek wording free of discriminatory overtones.

Only members of the association may submit articles to $P M L A$. Each article submitted is sent to at least one consultant reader and one member of the Advisory Committee. Articles recommended by these readers are then sent to the members of the Editorial Board, who meet periodically with the editor to make final decisions. Until a final decision is reached, the author's name is not made known to consultant readers, to members of the Advisory Committee and the Editorial Board, or to the editor. Because the submission of an article simultaneously to more than one refereed journal can result in duplication of the demanding task of reviewing the manuscript, it is $P M L A$ 's policy not to review articles that are under consideration by other journals. An article found to have been submitted elsewhere will not be published in PMLA even if it has already been accepted for publication by the Editorial Board.

Submissions, prepared according to The MLA Style Manual, should be sent in duplicate and addressed to the Managing Editor, PMLA, Modern Language Association, 10 Astor Place, New York, NY 10003-6981. With each submission please include a self-addressed envelope and enough postage for both copies to be returned. Authors' names should not appear on manuscripts; instead, a cover sheet, with the author's name and address and the title of the article, should accompany each manuscript. Authors should not refer to themselves in the first person in the submitted text or notes if such references would identify them; any necessary references to the author's previous work, for example, should be in the third person.

\section{Criticism in Translation}

MLA members are invited to submit to the PMLA Editorial Board proposals for translations. Articles, as well as chapters or sections of books that can function as independent units, will be considered. The originals may be in any language. Two types of proposals are welcome: (1) significant scholarship from earlier periods that has not lost its forcefulness and whose retrieval in English in PMLA would be a noteworthy event for a broad body of readers or (2) contemporary work of sufficient weight and potential influence to merit the attention of the field as a whole.

A member who wishes to make a proposal should first ascertain that no previous English translation exists. The proposer should then provide the managing editor with the following materials: (1) a photocopy of the original essay, (2) an extended summary of the entire essay in English, (3) an introductory statement of approximately 1,000 words, prepared in accordance with MLA style, that will be published with the essay if the essay is accepted, (4) information on the copyright status of the original (if the translation is accepted for publication, the proposer will be responsible for obtaining permission to print it). In addition, if the proposer wishes to serve as translator of the essay or to designate a translator (who must also be an MLA member), a 1,000-word sample of the translation should be submitted; otherwise the Editorial Board will select a translator.

The translated essays should normally not exceed $P M L A$ 's 9,000 -word limit. The Editorial Board will approve or decline the proposals, evaluate the quality of the translations, and cooperate with the proposers and translators. 


\section{Contents}

Forthcoming in PMLA . . . . . . . . . . . . . . . . 182

Editor's Column . . . . . . . . . . . . . . . 183

\section{Cluster on Early Modern Women}

\section{Introduction}

Ann Rosalind Jones

Botticelli's Madonna del Magnificat: Constructing the Woman Writer in Early Humanist Italy Susan Schibanoff . . . . . . . . . . . . . . . . . . 190

Sorceresses, Love Magic, and the Inquisition of Linguistic Sorcery in Celestina

Olga Lucia Valbuena

Rabelais, Misogyny, and Christian Charity: Biblical Intertextuality and the Renaissance Crisis of Exemplarity François Rigolot.

Hemans and Home: Victorianism, Feminine "Internal Enemies," and the Domestication of National Identity Tricia Lootens . . . . . . . . . . . . . . . . . . . . . 238

Spectacular Sympathy: Visuality and Ideology in Dickens's A Christmas Carol Audrey Jaffe

Myths of Anthropology: Eliot, Joyce, Lévy-Bruhl

David Spurr

Forum ...................... 281

Forthcoming Meetings and Conferences of General Interest . . . . . . . . . . . . . . . . 286

Cover illustration: Urs Graf, after Hans Baldung Grien, Witches' Sabbath, 1514, pen on reddishbrown paper, heightened with white, $11^{1 / 2} \times 8^{1 / 2}$ in. $(29.4 \times 21.6$ $\mathrm{cm})$, Graphische Sammlung Albertina, Vienna.
Index of Advertisers . . . . . . . . . . . . . . . . . 287

Professional Notes and Comment . . . . . . . . . . 302 Announcements 302

Journal Notes 306

Meeting of the MLA Executive Council 310

In Memoriam 316

Abstracts ..................... 351 